\title{
$3 \quad$ A Right to Recreation: Provincial Policymakers Design Cycling Networks
}

"Actually, the construction and maintenance of cycling paths is a government task for municipalities," a journalist wrote in 1949. "It is fortunate that this Twente organization, founded on January 6, 1917, has taken this governmental work upon itself because otherwise, the condition of many cycling paths in Twente would almost certainly be a lot worse than it is now."1 He praised the Twente cycling path organization for its valuable service to society - but also implicitly critiqued local government for ignoring a public task. Constructing 1,00o km of cycling paths in the eastern region of Twente had not been easy: local municipalities invested very little, and funding had to come from elsewhere. Both tourists and commuters were served: Twente had a significant textile industry, so to provide mobility options for its workers, major industrialists sponsored path construction through the Chamber of Commerce. The region also received small sums from the tourist organization (ANWB), the tourist board (VVV), the district water board, the farmers union, the agricultural loan bank, and dairy factories. The plethora of contributors reveals the broad support for cycling infrastructure in this prominent textile region. By the late 1940s, a growing chorus of voices called for local authorities to take up a larger role in cycling governance and not leave it all to the energy and initiative of others. Finally, the 1930 call from the Loosdrecht accountant with which our story started seems to resonate: building cycling path should be the government's task.

Some of the earliest policymakers to realize this were in the province of Drenthe. Wanting to take up the construction of cycling paths as a state task, policymakers decided to establish a cycling path organization in 1940. At their founding meeting, a key member of the successful sister organization in neighboring Twente (in the province Overijssel), L. Vincken, advised Drenthe "to concentrate not only on paths with a recreational interest, but also on utilitarian paths [utiliteitspaden] to obtain financial support from residents." Vincken's underlying strategy was opportunistic: get funding for recreational cycling paths by stressing cycling paths' economic uses. Hendrik

$1 \quad$ “De Rijwielpadvereniging Twente: Haar werk en haar vele moeilijkheden," Twentsch dagblad Tubantia, April 30, 1949, 2.

2 DA 0196, inv. no. 544, minutes foundation meeting Drenthe cycling path organization, May 7, 1940. 
Wytema, mayor of one of Drenthe's municipalities, agreed, pointing to the 1930 s crisis funding that deployed jobless workers to construct cycling paths. Those plans were also for "utilitarian paths" and had a broader political support than the purely recreational paths, he counseled. ${ }^{3}$ In the context of the 193 os economic crisis, the liberal clubs found tourism was less of a priority. They needed other arguments to convince social democrat and confessional parties to invest in cycling. Vincken and Wytema perhaps realized that utilitarian cyclists formed a larger group supported by labor parties than purely recreational ones reputed to benefit the well-to-do. Their claims for state involvement were more likely to succeed if both groups would benefit from cycling paths.

What arguments did the organizations use to convince local government to become more active in cycling governance? And why were provincial and municipal politicians so eager to build cycling paths at a time when around the world, policy attention on cycling was reaching a low point? Framing cyclists as either predominantly utilitarian or recreational was a strategy that non-governmental organizations applied opportunistically to secure government subsidies. Stressing the bicycle's utilitarian potential turned out to be a good strategy. And it proved to be successful.

While scholarship has paid attention to recreational cycling in its early bourgeois culture, it has ignored its crucial history in mid-century as missing link to the 1970s expansion of utilitarian cycling. Moreover, for the 1950s, the scant scholarship focuses on urban commuters, but not on how recreational cycling helped sustain and expand cycling infrastructure. This chapter, entitled "A Right to Recreation: Provincial Policymakers Design Cycling Networks," uses untapped archival material to reveal how provincial politicians and public works departments initiated new cycling policies for regional recreational cyclists in the 1950s and 1960s. My argument provides a counterweight to the dominant narrative of cycling's decline in this period. A coalition of state and non-state actors believed that recreational cycling could solve concerns over public health and boost tourism - as two case studies illustrate - and invested in cycling accordingly. Policymakers in the densely populated province of Zuid-Holland introduced policies to improve its residents' lives, while the poor agricultural province of Drenthe saw the economic potential of attracting middle-class cycling tourism. Interested in social uplift, social democrat politicians pushed to create recreational opportunities for the city's working and middle classes. Only in the 196os would the national government start to follow suit and support provincial initiatives. 


\subsection{Pioneering Recreational Cycling Governance in the $1940 \mathrm{~s}$}

When non-governmental cycling path organizations had sought Dutch state funding, they had made a case for their cycling infrastructure by underlining that it was a public good, serving both recreational and utilitarian purposes. However, their attempts to acquire national funding in the 1930 s had failed. National policymakers argued that (recreational) cycling was a local concern, to be handled by local government. At the same time, as we have seen, public works engineers at national and provincial levels remained committed to building separate cycling paths alongside roads, which they considered utilitarian. In contrast, the cycling paths discussed in this chapter had their own trajectory. These did not follow the road network, but were recreational, meandering through the landscape. Over time, policymakers began to realize that this division was too simplistic: separate cycling paths that were not alongside main roads also served commuters and were mixed-use. In 1940, this problematic distinction between utilitarian and recreational cycling infrastructure was what had prompted Drenthe's policymakers to establish a cycling path organization.

The effects of the war proved important. Around mid-century, local policymakers, increasingly recognizing the public service that the cycling path organizations provided, for example, financed much-needed repairs to the paths damaged in the war. ${ }^{4}$ State reconstruction agencies offered the organizations interest-free advances for the repair work. The tourist organization ANWB mediated between these agencies and the local cycling clubs in complex and time-consuming administrative procedures. ${ }^{5}$ The state did accept the war damage claims. It shows the government started to recognize the private organizations' work as a public service. In 1950, for instance, Utrecht's provincial government strongly recommended that municipalities raised subsidies to repair war damage to the local cycling path organization's network (UMO). Municipalities had to "award and/or

4 Two ANWB officials, engineers Lorié and Tusenius, visited cycling path organizations throughout the country and together with local officials made an inventory of the war damage: ANWB archive, inv. no. 1225 and for specific organizations ANWB Archive, inv. nos. 1113, 1115 (Gooi en Eemland), 1184 (Noord-Kennemerland), 1191, 1193 (UMO), 1209 (Walcheren), 1220 (Twente), and 1231, 1243 for an FNRV overview. The ANWB urged organizations to take advantage of the financial claims as some boards had become rather inactive over the years.

5 The ANWB was an intermediary in these contacts with the Ministry of Finance's Reconstruction Agency (Bureau Financiering Wederopbouw Publiekrechtelijke Lichamen): ANWB archive, inv. no. 1191, letter UMO to Bureau, May 15, 1946 and letter ANWB to Bureau, June 15, 1946. UMO submitted a total of forty-four damage claims. After approval by the provincial state engineer, the ANWB forwarded requests to the Ministry's policymakers. 
increase a reasonable yearly contribution" to UMO "which in effect takes care of the government's tasks." ${ }^{6}$ The ANWB and the UMO lobby succeeded in getting state recognition.

In the immediate postwar period, provincial authorities were increasingly involved in recreational cycling. Due to the Netherlands' decentralized governance structure, each province had slightly different plans and funding procedures, as a 1938 ANWB report demonstrates. ${ }^{7}$ Zuid-Holland was working on its newly designed cycling path plan; as did other provinces like Drenthe, Noord-Brabant, and Limburg. Some provinces contributed by subsidizing a fixed amount or percentage per kilometer of constructed cycling path. ${ }^{8}$ These provincial subsidies often stipulated that the cycling paths had to serve a public need: in Utrecht subsidies were only awarded to "paths which were considered of sufficient general interest." The province Gelderland's chief engineer emphasized that provincial subsidies were only meant for "bicycle tourism ... because bicycle traffic indicates an entirely different concept. ${ }^{{ }^{10}}$ The funding streams for cycling paths alongside roads (seen as utilitarian) and recreational cycling paths were separate, as were the governance coalitions.

In 1946, the Federation of Dutch Cycling Path Organizations resubmitted its prewar request for national subsidies. The federation stressed the bicycle's all-purpose postwar use, because due to shortages, "in the coming years, the bicycle will (have to) be used a lot."11 The organizations employed their preferred strategy of stressing cycling paths' mixed use to argue that tourism was not the primary goal. The paths served "numerous daily bicycle commutes for agricultural and factory-workers" and diverting cyclists from main roads was an additional reason to invest heavily in cycling infrastructure. ${ }^{12}$ The

6 HUA 1007-3, inv. no. 30791, letter Utrecht province to municipalities, September 12, 1950.

7 Note again how hand in glove the Public Works department worked with the ANWB; the distinction between state and non-state actors was almost meaningless.

8 Overijssel provided 7.50 guilders per year $/ \mathrm{km}$ of cycling paths. In Gelderland, the provincial executive chose paths it would finance (25 guilders per year $/ \mathrm{km}$ to a maximum of $18 \mathrm{okm}$ ). Shortly after World War II, in a renewed attempt to boost tourism, this subsidy rose to 75 percent of maintenance costs, with a maximum of 75 guilders per km: Gelders Archief (hereafter: GA), 0039 (Gedeputeerde Staten 1814-1950), inv. no. 9482, subsidies to cycling path organizations 1927-1949; GA 3204 (GS 1950-1979), inv. no. 7173, letter GS to provincial roads committee, November 26, 1947 .

9 NA 2.16.11, inv. no. 436, memorandum 'Nota naar aanleiding van het Adres van de Federatie van Nederlandsche Rijwielpadvereenigingen.'

10 GA 0039, inv. no. 9482, letter HID Kempees to cycling path organization Oostelijk Gelderland (BROG), February 11, 1932.

$11 \quad$ NA 2.16.11, inv. no. 436.

12 Ibid. Letter May 14, 1946. 
ANWB agreed this was in the public interest: "a network of well-constructed utilitarian and recreational cycling paths would fulfil ... a pressing need." ${ }^{\prime 3}$ The Minister of Public Works' national advisors also deemed "a cycling path network covering the entire Netherlands of such great importance for the Dutch people ... there is every reason to systematically design such a plan."14 The Ministry, however, decided that coordination and construction fell to new provincial bodies rather than the national government.

In the 1940s, policymakers systematized the planning of land use, including recreation, under a new agency coordinating the efforts. ${ }^{15}$ During the war, the German occupiers of the Netherlands introduced a national spatial planning agency (Rijksdienst voor het Nationale Plan) in $1941 .{ }^{16}$ Each province had its own planning agency (Provinciale Planologische Dienst), also overseeing recreation. After the war, the government established the new Ministry of Social Work in 1952, becoming the Ministry of Culture, Recreation, and Social Work in 1965 that would subsidize recreational cycling infrastructure (see 5.3). ${ }^{17}$ The provinces' recreational cycling path design reflected growing government intervention in leisure and recreation policy, as well as designs for spatial planning and nature preservation. Since the 1940s, this process tended to sideline non-governmental actors, diminishing the role for private initiative. At the same time, it also marked cycling governance's increasing professionalization. The policy's main implementors were the provinces and municipalities working together regionally.

In the late 1940s and 1950s, some local policymakers created organizations to design regional (recreational) cycling networks. ${ }^{18}$ Others transformed existing private organizations into state agencies, taking over their privately built networks. Many municipalities, especially in the touristic Veluwe region, took up this initiative energetically in the late 1940s, seeing opportunities for developing tourism. For example, the founder of Zuid-Veluwerand, the cycling path organization around the nation's key nature reserve area in 1949, was the mayor of the town Barneveld. He invited local mayors, tourist organizations

13 Ibid.

14 Ibid. Concept advice 1946.

15 Faludi and Van der Valk, Rule and Order, 64, 74, 97; Mom, "The West and the Rest"; Van der Cammen and De Klerk, Ruimtelijke ordening, 152-65; Mom and Filarski, De mobiliteitsexplosie, $255-56$.

16 Its first director was Frits Bakker Schut, son of prominent social democratic The Hague city planner Piet Bakker Schut.

17 Ido de Haan, Jan Willem Duyvendak, and Maarten van Bottenburg, In het hart van de verzorgingsstaat: Het ministerie van Maatschappelijk Werk en zijn opvolgers (CRM, WVC, VWS), 1952-2002 (Zutphen: Walburg Pers, 2002).

18 E.g. the organization Zuid-Veluwerand (founded in 1949, ANWB archive, inv. no. 1199). 
(VVV), along with the province's chief engineer J.G. Kruimel and ANWB engineer C.A. Kuysten to take part. ${ }^{19}$ Kruimel clarified provincial subsidy opportunities, while Kuysten explained the wider construction context and procedures elsewhere. The governance network consisted exclusively of regional policymakers (mayors), provincial policymakers (engineers), and the (national) non-governmental tourist organizations VVV and ANWB, functioning as advisors. The national government barely played a role. ${ }^{20}$

\subsection{Pioneering Provincial Cycling Governance in Drenthe and Zuid-Holland}

Stimulating cycling in Drenthe was a means to an end. Compared to densely urbanized Zuid-Holland, which supported cycling for public health reasons for its urban working classes, Drenthe was a sparsely populated, poor, and rural province. Drenthe actively promoted cycling (tourism) as a way to boost its economy. Before World War II, Drenthe had an active private cycling path organization and, uniquely, early state involvement with cycling. The local bourgeoisie in Drenthe created a non-governmental organization in 1916. By 1937, it had constructed $100 \mathrm{~km}$ of paths. At that point and in the midst of the economic crisis, provincial policymakers took an interest in cycling path construction, even though the Drenthe branch of the Dutch Municipalities Association's (Vereniging Nederlandse Gemeentes) application to the national government for more cycling paths had been recently rejected. A key figure behind the promotion of cycling paths was the Royal Commissioner for Drenthe, the conservative liberal baron Reint Hendrik de Vos van Steenwijk. A doctor of law, he belonged to a prominent family and was a long-time member of the Upper House of Parliament. His goal was to improve the economic situation of the relatively poor province of Drenthe. To this end, he wanted to attract industry and tourism, partly by improving

19 ANWB archive, inv. no. 1199, "Kort verslag van het verhandelde in de vergadering van 10 Februari 1949."

20 Other examples of new public cycling path organizations, or private organizations taken over by the state, include Noord-Veluwe (ANWB archive, inv. no. 1226) and VRIGA in the Achterhoek region (both in Gelderland province) as well as organizations in Noord-Brabant province: Brabant Centrum, De Kempen, Markiezaat Bergen op Zoom, and later the Baronie van Breda. See also "Heden en toekomst van de rijwielpaden," De Kampioen 53, no. 16 (1936): 266-67; "Rijwielpaden in de Geldersche Achterhoek," De Kampioen 62, no. 11 (1947): 329; C.A. Kuysten, "Rijwielpaden in Zuid-Holland," De Kampioen 62, no. 9 (1947): 274-75; "Rijwielpadennet in het centrum van Noord-Brabant," De Kampioen 67, no. 12 (1952): 348-49; “Fietsen op de paden van de Zuid-Veluwe," De Kampioen 75, no. 6 (1960): 176-77. 
Drenthe's infrastructure. He took the initiative for the Development Agency for Drenthe (Centrale Vereeniging voor den Opbouw van Drenthe). ${ }^{21}$ Cycling path construction was one public works administration project that fitted in with these goals and would also address the massive youth unemployment in Drenthe during the 1930 s economic crisis. ${ }^{22} \mathrm{He}$ appointed some mayors and the Development Agency's director Jaap Cramer to form a committee for this purpose. Cramer was a social democrat who would succeed De Vos van Steenwijk in $195^{1}$ as Royal Commissioner for Drenthe. While of different political affiliations, both were elite figures with good connections, in a position to realize their vision for Drenthe. Authorities in Drenthe pioneered the funding and building of the regional cycling path network in the late 1930 s as a public works project to combat unemployment and create prosperity through a program of infrastructure construction. ${ }^{23}$

Drenthe also pioneered cycling governance. It was unclear which agency should be responsible for cycling paths. While the discussions in the late 193 os had shown the state's reluctance to do anything more than construct commuter cycling paths alongside roads, Drenthe decided to take the lead. The inspector for youth unemployment argued that Drenthe's municipalities were too poor to contribute: municipal plans would only cover parts of the province. A provincial initiative would be a faster and more streamlined process. The inspector also advised to start quickly on a pilot, not to wait until the completion of a comprehensive plan. Building one path immediately would "rouse interest from other parts of the province."24 Head of the Development Agency Cramer sought funding higher up, asking the ANWB, and significantly not the national government, to "function as a funnel for national subsidy." ${ }^{25}$ Cramer obviously hoped that the ANWB's good contacts with national government would guarantee funding, but he was mistaken. ANWB engineer De Bruyn, a member of the national Roads Consultation Committee (see Chapter 2) responded that neither the state nor the ANWB was likely to provide the funding. ${ }^{26}$ Still, the very well-connected De Vos

21 DA 0196, inv. no. 544, letter Royal Commissioner Drenthe to nominated members subcommittee cycling paths, February 19, 1937.

22 On using unemployed people in public works: Van der Woud, Het landschap, de mensen. Nederland 1850-1940.

23 W.J. Simons, Daar fietst men toch zo heerlijk heen:vijftigjaar Provinciale Drentse Rijwielpadvereeniging/Stichting Het Drentse Fietspad (Assen: Stichting Het Drentse Fietspad, 1990).

24 DA 0196, inv. no. 544, meeting sub-committee on the construction of cycling paths by young unemployed people, March 11, 1937.

25 DA 0196, inv. no. 544, letter Cramer to ANWB (De Bruyn), February 5, 1940.

26 Ibid., letter De Bruyn to Cramer, March 7, 1940. 
van Steenwijk and Cramer knew the rules of the political game - what arguments to employ and which people to approach to achieve their goals.

Provincial cycling coordination required a new agency and external expertise. When Drenthe formed its Provincial Cycling Path Organization, its founding meeting in 1940 was an interesting event from a governance perspective: it demonstrates how knowledge traveled between provinces, without the national government's involvement. Vincken attended the meeting to suggest key strategies and best practices from Overijssel and as representative of the National Federation of Cycling Path Organizations. The Twente region of Overijssel received annual subsidies from the province on two conditions: that a path's quality was approved by a provincial inspector and that it was of "provincial interest." The province apparently considered this to be the case for $300 \mathrm{~km}$ of the Twente organization's $900 \mathrm{~km}$ network. In addition, Twente received 1,00o guilders as an annual subsidy from the local Chamber of Commerce "because factory workers benefit from the paths," proving that many paths were indeed used for both recreation and commuting. ${ }^{27} \mathrm{~A}$ broad range of actors subsidized the organization's activity. Vincken's presence and central role in the founding of Drenthe's cycling path organization demonstrate how the provincial and regional cycling path organizations networked and shared expertise and best practices at a sub-national level.

Dutch provincial authorities also shared knowledge on governing (recreational) cycling. The Cycling Path Organization Drenthe worked with the province's Public Works chief-engineer, Willem Izak Cornelis van Veelen. He quizzed colleagues in other provinces on how they went about gaining support for rural cycling path improvement and construction, in other words those paths not alongside roads. ${ }^{28}$ Was there a private cycling path organization or a "semi-official" one consisting of municipalities, or was the province directly involved? And which organizational form did other provincial engineers prefer? Van Veelen enquired whether the other provinces already had a rural (landelijk) cycling path plan. If so, how was it structured. He also wanted to find out the various provincial conditions for cycling path subsidies. Van Veelen needed the information as input for Drenthe's policy to support the Provincial Cycling Path Organization, and so he urged his colleagues to reply swiftly. Within a few months, all the provinces had provided detailed responses about their plans, allowing Van Veelen to draw up a memorandum summarizing provincial cycling policy 
in $1951 .^{29}$ The provinces were aware that private organizations existed and were now seeking cooperation, having sparingly subsidized them for decades.

With the input from other provinces, the Provincial Cycling Path Organization Drenthe formulated its tourism-oriented "Central Cycling Path Plan" in $195^{2}$ - updated and expanded in 1959. A key figure ("the great promotor and animator" as one newspaper called him) behind the plan was Gerard Adriaan Maarten van den Muyzenberg, an official in Drenthe's Public Works department. ${ }^{30}$ As the organization's secretary and treasurer from 1950 until 1974, he and his colleagues designed a $400 \mathrm{~km}$ cycling path network, dependent on national subsidies. Drenthe would have needed fifty years to implement the plan without such a subsidy. In its address to the national government, Drenthe Public Works administration framed a provincial cycling path network as a necessary condition for economic growth. According to the engineers, Drenthe had huge tourism potential and "the cycling path network contributes substantially in boosting a healthy provincial economic structure. A completed cycling path plan constitutes the "framework" that has to be furnished with holiday centers, catering companies, and amusement facilities. ${ }^{31}$ In other words, recreational cycling paths were necessary to lift Drenthe from its economically disadvantaged position. Cycling tourism was the key to that end (see figure 12).

The province framed the cycling paths in a broader light, however. Chairman of the Provincial Cycling Path Organization Drenthe's board, Jan Antonie Reinders Bosma (the former mayor of Winterswijk in the province of Gelderland) refused to distinguish recreational and utilitarian cycling paths: the organization dealt with cycling paths "in general." ${ }^{22}$ Cycling paths relieved traffic on the major roads - a remarkable argument given Drenthe's low car ownership in the 1950 os. $^{33}$ Cycling paths would improve the connection between industrial and commuter areas as well as end the

29 DA 0924, inv. no. 167, "Nota betreffende het beheer, de subsidiëring, de plannen en de wijze van aanleg van landelijke rijwielpaden in de verschillende provincies van ons land," 6-7.

$3^{0}$ "G.A.M. v. d. Muyzenberg promotor Drents fietspad vertrekt op 13 december," Nieuwsblad van het Noorden, November 30, 1974, 15 .

31 DA 0923, inv. no. 6258, letter Public Works Drenthe to Ministers OKW/EZ/SZ, December 4, 1959 .

32 DA 0196, inv. no. 544, foundation meeting Drenthe cycling path organization, May 7, 1940.

33 Wolf, "Following America? Dutch geographical car diffusion, 1900 to 1980" (PhD diss., Eindhoven University of Technology, 2010), 75. 


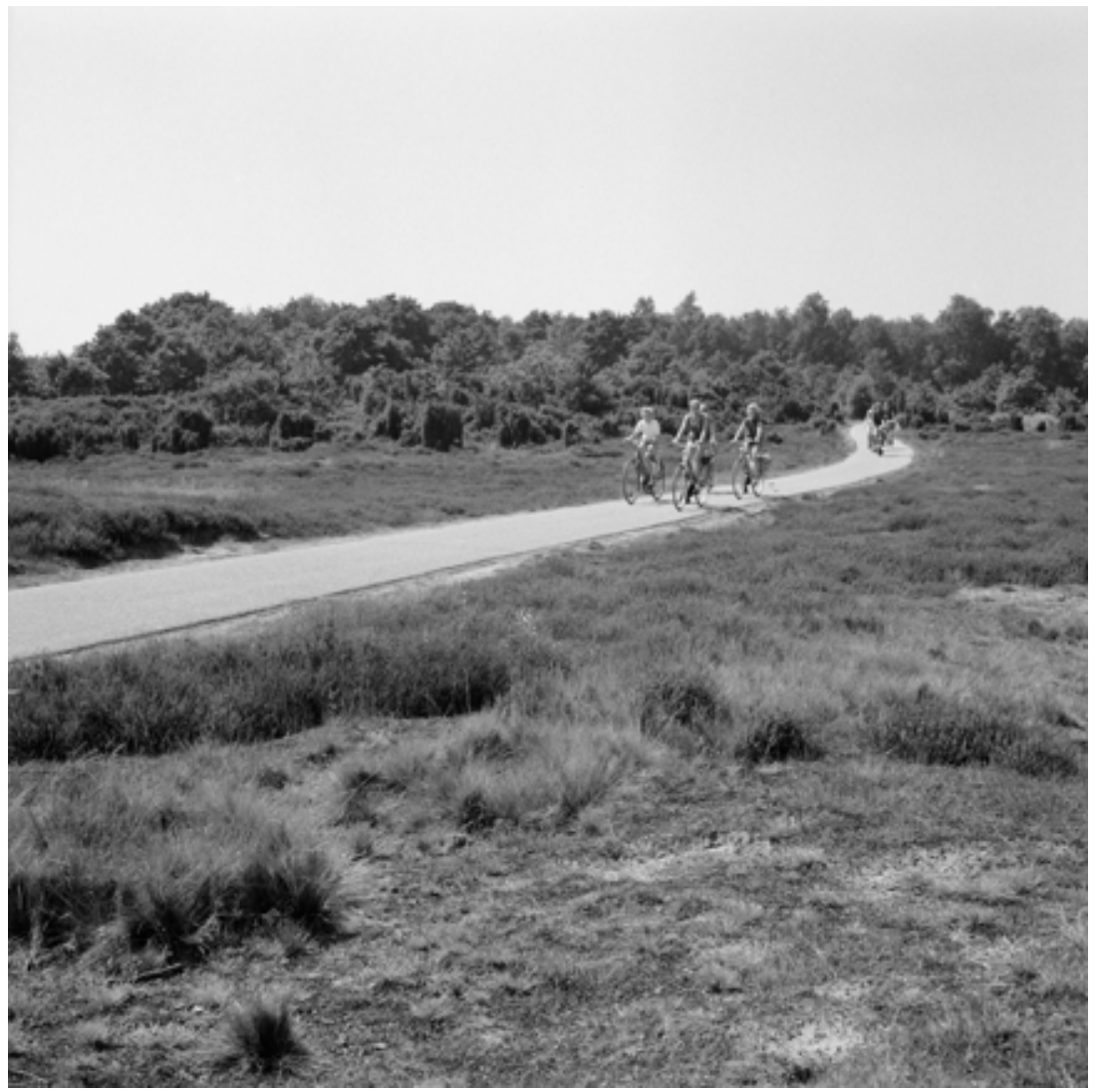

Figure 12 Policymakers in Drenthe felt their province could attract tourists and improve the economy through a network of appealing cycling infrastructure. Here tourists enjoy riding on a cycling path constructed near Ruinen, 1965, part of the provincial recreational cycling path plan. [Source: National Archives, Fotocollectie Nederlandse Heidemaatschappij, Photographer unknown/Heidemij., no. 161-1396]

isolation of certain rural areas. ${ }^{34}$ These appeals were probably strategic, aimed at acquiring more funding.

The strategy targeting economic growth and utility succeeded because many government bodies funded Drenthe's cycling path plan. In 1955, the Drenthe provincial legislature approved a 500,000-guilder subsidy.35 The local communities contributed 7.5 percent, the province added 20 percent. The remaining 72.5 percent was state funding, with the Ministry of Economic Affairs picking up 42.5 percent, and the Ministry of Social Affairs 30 percent. 
By the 196os, the new Ministry for Culture, Recreation and Social Work did subsidize recreational cycling. The Ministry of Public Works was not even considered for funding as it did not regard recreational cycling its responsibility. The contribution from Economic Affairs was unusual, but Drenthe's official designation as economic development area made it eligible for funding. ${ }^{36}$

The right people in the right place made all the difference. Drenthe's Jaap Cramer lobbied national policymakers, and what is more, he was great at playing the publicity game. When the cycling path plan's implementation stalled, Cramer's stunt was to organize a visit from the royal family, resulting in a widely disseminated picture of Queen Juliana cycling on the paths. He then used the queen's interest in the plan to put pressure on the government: there were regular meetings between the Royal Commissioners and the Queen, which helped Cramer keep up the momentum for funding the plans (see figure 13).37 Van den Muyzenberg's longtime position in provincial Public Works made him another key spider in the web. Individuals mattered in Zuid-Holland as well.

In the 1950s, Zuid-Holland was one of the first Dutch provinces to devise a provincial "Cycling Path Plan." Revisions and updates over the following decades allow us to track the plan's changing notions of what cycling meant to provincial policymakers. Zuid-Holland forms a different case than Drenthe. The motivation behind the plan was a social democratic conviction that provincial authorities should provide healthy recreational facilities for urban working people. In densely populated Zuid-Holland, with large cities like Rotterdam and The Hague, this was a particular concern in the late 1940 s and early 1950 s. $^{38}$ The province commissioned a short film in 1954 to introduce the new recreational area Brielse Maas, east of Rotterdam, explicitly targeting city-dwellers. Called Free Outdoors (Vrij Buiten), the drama illustrates the ideology behind the plan. ${ }^{39} \mathrm{~A}$ stressed city bank employee seeks in vain a little peace and quiet on a busy beach. Finally, he finds tranquility and relaxation by taking a cycling trip on paths through Zuid-Holland's nature, far from any noisy cars or traffic. The film represented a new insight in policy circles. According to provincial engineer Fekkes in 1956, "in a wide circle, the realization is growing that on a larger scale than hitherto, provisions have to be made" for cyclists and mopeds, particularly "by creating possibilities for

36 Simons, Daar fietst men toch zo heerlijk heen, 6 o.

37 Piter Bergstra and Martin de Bruin, "Een goede CdK opent Haagse deuren," Nieuwsblad van Friesland, August 27, 1994, 23.

38 Harm Kaal, "Ruimtelijke ordening," in Behoedzaam bestuur. Twee eeuwen provincie ZuidHolland, eds. Roel Pots and Nico Randeraad (Leiden: Primavera Pers, 2014), 156-57.

39 The film is on archief.zuid-holland.nl under "Vrij Buiten." 


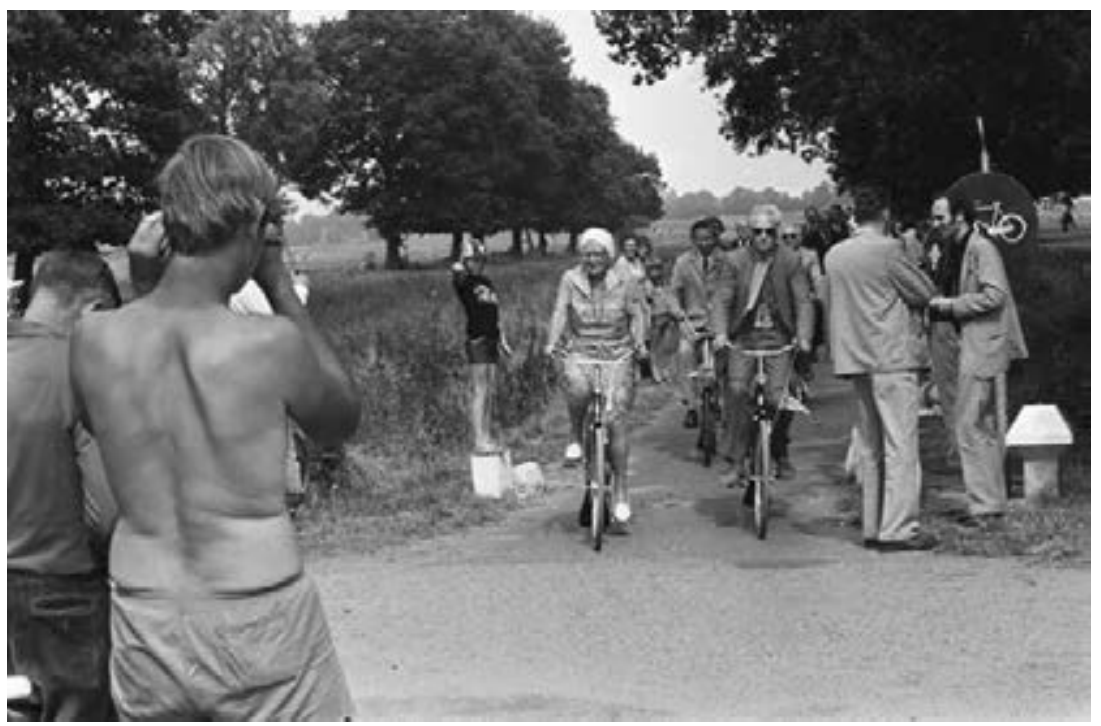

Figure 13 Keen cyclist Queen Juliana of the Netherlands visited Drenthe on many occasions. In 1975, during the tenth Four Day Cycling event (Rijwielvierdaagse), she cycled over one of the province's many recreational cycling paths. [Source: Rob Mieremet, Nationaal Archief / Anefo, no. 928-0377]

recreational cyclists to travel by good and attractive cycling routes. ${ }^{\text {"mo }}$ Fekkes explained that such paths would follow Zuid-Holland's many waterways or connect villages to public pools or beaches.

The Zuid-Holland cycling path policy only financed paths that were not parallel to the road network. Separate cycling paths alongside major roads did not qualify. Policymakers considered these an integral part of the road already funded and governed by national and provincial government public works departments. Politicians and engineers tended to see these paths that lined the country's main arteries as serving a predominantly commuter function. This clashed with the plan's goal - to provide a quiet, relaxing ride in the countryside. Under the plan, paths had their own trajectories, sometimes former rail- or tramway lines. ${ }^{41}$ Engineers had to meet high design standards for paths: 3 meters wide and asphalted..$^{42}$ While the substantial paths along roads served utilitarian cyclists, provisions for recreational traffic fell short. As this traffic needed paths with a separate trajectory, Fekkes

40 J.C. Fekkes, "Provinciaal Rijwielpadenplan voor Zuid-Holland," Wegen 3o, no. 1 (1956): 1-2.

41 Examples from the 1950s include the tramway in the Hoeksche Waard between RotterdamZuid and Oude Maas (NA 3.02.27, inv. no. 1559); between Goedereede and Melissant (NA 3.02.27, inv. no. 1339); and in the 1970s, the former tramways between Wassenaar and Leiden and in Naaldwijk (NA 3.02.27, inv. no. 2918 and 2923).

42 "Nieuwe rijwielpaden in Zuid-Holland," Trouw, August 13, 1959. 
set "great store by opening up the province through the construction of a touristic cycling path network. ${ }^{n 3}$ For provincial policymakers, recreational cycling was an important public good.

This commitment to providing recreational opportunities had a social democratic pedigree. In Zuid-Holland, Provincial Executive (Gedeputeerde Staten) politicians rather than provincial public works administration(PWS) engineers initiated the provincial cycling plan. Provincial politician Stien de Ruyter-de Zeeuw was the major initiator of this policy in the 1950s and 1960 s. ${ }^{44}$ With a background in radical socialist movements, in 1946 she represented the social democratic SDAP party (later the labor party PvdA). ${ }^{45}$ When she left the Provincial Executive in 1970, she was praised for her role in creating cycling paths and recreational facilities. ${ }^{46}$ As a workers' advocate, she believed in the right to "possibilities for recreation and nature" close to the city for "people without a car."47

A later successor, fellow social democrat Joop Borgman, took up the torch. He was Provincial States member from 1962 and Provincial Executive member from 1974 until 1987, the period when the provincial recreational plan was reanimated and substantially revised. His interest in (recreational) cycling is also evident from his post-retirement role as director of the National Cycling Platform (Landelijk Fietsplatform), an independent coordinating agency for recreational cycling, from 1991 until his death in 1999. ${ }^{48}$ In an interview with newspaper Trouw in 1978, Borgman strongly supported creating and promoting a recreational cycling network. He also emphasized how much road traffic safety had improved in the past two decades thanks to widespread cycling path construction alongside most secondary and tertiary roads. ${ }^{49}$ This reflects policymakers' growing focus on utilitarian cycling in the 1970s. In short, since the postwar decades, cycling in Zuid-Holland had strong supporters within the Provincial Executive. Implementation of the recreational

43 Fekkes, "Provinciaal Rijwielpadenplan voor Zuid-Holland" (1956), 1-2.

44 Dick Linders, "Mr. Chr. A. De Ruyter-De Zeeuw, Rotterdam 22 Aug 1907 - IJlst 5-12-1995, Onafhankelijk, sociaal-democraat," Rotterdams Jaarboekje Series 10, no. 4 (1996), 146-53; Kaal, "Ruimtelijke ordening," 167.

45 The SDAP merged with two other parties to form the PvdA in 1946, the major social democratic party in Dutch politics.

46 Linders, "Mr. Chr. A. De Ruyter-De Zeeuw," $15^{2}$.

47 Ibid., 152 .

48 For Borgman, see https://www.parlement.com/id/vgogllponlz5/j_joop_borgman, biography consulted September $7,2018$.

49 Haro Hielkema, "Zuid-Hollandse fietsers krijgen meer de ruimte: Gedeputeerde Borgman kan nog wel paar miljoen gebruiken," Trouw, November 10, 1978, 6. 
plan may have been slow - requiring a constant battle for resources and engineers' attention - but this long-term political commitment by Zuid-Holland social democrats to recreational cycling was a crucial success factor.

\section{Digging Up Data}

Politicians in Zuid-Holland struggled to get provincial engineers to implement cycling plans. To make a proper cycling policy, a first step was an inventory of existing cycling paths in the province. No such overview existed. The lack of a coordinating agency for cycling meant that Zuid-Holland's engineers had the painstaking and time-consuming task of compiling this information, as shown in figure 14. There were paths alongside roads, governed either by national or provincial government (in green). Then there were separate paths in the provincial cycling path plan (black), or built by other organizations (blue). All these authorities had constructed paths, but many from the late 1950 on only existed on paper (the paths in red). That is why this map has so many different colours.

A similar request by the Provincial Executive in the province Gelderland was also time-consuming for Public Works. It asked for the extent of existing cycling paths and the cost of further construction.

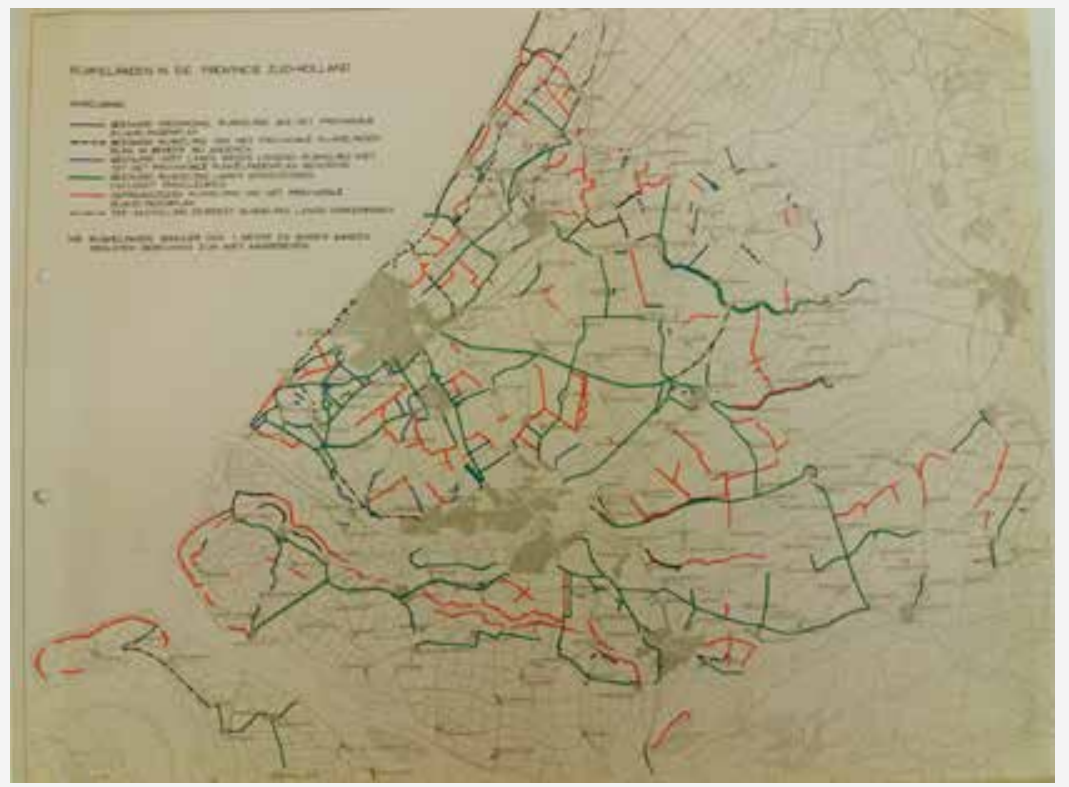

Figure 14 Map of cycling paths in Zuid-Holland province, c. 1959. [Source: NA 3.02.27, inv. no. 1559] 
In February 1949, politicians reminded engineers that they had still not provided this information requested in April 1948. The Gelderland engineer eventually responded, telling them in no uncertain terms how expensive cycling path construction would be, requiring "very extensive preparation," and it could only be "implemented very gradually." Politicians were irritated by this negative response: cycling paths alongside roads were needed urgently: a temporary and cheaper construction was one option.

In the 1960s, implementation of the Zuid-Holland plan was slow. Engineers blamed this on lack of technical personnel and frankly admitted that roads were their priority. But finding out how provincial engineers spent their budgets remained an issue well into the 1970s. Politician Joop Borgman complained that the plan's progress reports gave no insight into what percentage of the budget for improving road surfaces went to cycling paths or to roads. This information was only obtained after multiple strongly worded letters and meetings with engineers. A true political decision about the distribution of funding was only possible once politicians knew how much money was actually being spent on improving conditions for drivers and cyclists. Civil servants' longevity in office fostered consistent policymaking and enabled long-term personal relationships between stakeholders, but could also lead to inertia and delay.

Sources: NA 3.02.27, inv. no. 1559, letters PWS to Gedeputeerde Staten December 14, 1959 and January 7, 1963; GA o039, inv. no. 9488, letters GS Gelderland to HID PWS, April 22, 1948, February 22, 1949, April 21, 1949, July 1, 1949; NA 3.02.46, inv. no. 2676.

Friction arose between politicians and provincial Public Works engineers: politicians' frequent calls to action suggest engineers were slow to implement the plan (see box). Initial objectives had to be scaled back multiple times. The first proposals in the mid-1950s were for $400 \mathrm{~km}$ of cycling paths. For budgetary reasons, provincial engineers proposed reducing the plan to $215 \mathrm{~km} \cdot .^{50}$ The five-year plan for realization adopted in 1959 counted $110 \mathrm{~km}$, a target not even reached by $1965 \cdot{ }^{51} \mathrm{In} 195^{8}$, provincial engineers acknowledged "the demand of your board to accomplish more in realizing the provincial cycling path plan than has happened in previous years." ${ }^{2}$ The Provincial Public Works' chief-engineer admitted he believed that roads

$50 \quad$ NA 3.02.27, inv. no. 1559, letter PWS to Provincial Executive, March 26, 1959.

51 Ibid., January $7,1963$.

52 NA 3.02.27, inv. no. 1559, PWS memorandum February 6, 1958 "Overzicht van de stand van zaken met betrekking tot de voorbereiding en de aanleg van het provinciale rijwielpadenplan.” 
had priority over cycling paths. For the delay, he also blamed the lengthy and costly process of land expropriation..$^{53}$ This was less of a problem for paths alongside roads because they were included in road budgets and expropriation procedures; but because recreational cycling paths had their own trajectory, they required legally and financially complex procedures. The process was not just an excuse by the engineers, as Joop Borgman later claimed. If landowners refused to part with their land, there was little the authorities could do. ${ }^{54}$ Despite fluctuating investments, the network grew steadily over the 1960 s and 1970 (see figure 15 ).

By the 1970s, Zuid Holland's expanded version - like other provincial plans - included utilitarian as well as recreational cycling, demonstrating a changed perception of cycling over the decades. According to the provincial public works engineers in 1975, "the bicycle's transport function" (vervoersfunctie) was valued more. 55 This new awareness was partly due to mobility statistics research, such as a 1974 Dutch Statistics Agency report which Zuid-Holland engineers cited. This showed that 29 percent of commuters still cycled.$^{6}$ More important was the 1970 s shifting political climate: cycling activism and growing concern over automobility's negative effects had changed policymakers' views on cycling, as Part III will demonstrate. Policymakers realized that the bicycle was not just for recreation, and once again recognized its actual and future role in transport. They designed the new cycling path plan with an additional $125 \mathrm{~km}$ of cycling paths also fit for utilitarian purposes. Likewise, the northern province Friesland introduced a recreational cycling path plan in 1962, updated in 1978 to include "cycling paths for daily use." ${ }^{57}$ The policymakers considered their ambitious plan a product of the previous recreational plan..$^{8}$ The institutional "cost" of introducing it was low, because public works could just copy the initial plan's procedures used in the 1950 s and $1960 .^{59}$ The only major difference was launching a much

53 Ibid.

54 Hielkema, "Zuid-Hollandse fietsers krijgen meer de ruimte."

55 J.P. Bakker and R. v.d. Hout, "Herziening provinciaal fietspadenplan Zuid-Holland," Verkeerskunde 26, no. 7 (1975): 356 .

56 Ibid., 359.

57 "Onzeker of provincie aanleg paden met geld kan steunen," Leeuwarder Courant, November 6, 1978 .

$5^{8}$ "Eerstkomende 15 jaar: bijna $25^{\circ}$ fietspaden erbij in Friesland," Leeuwarder Courant, December 1, 1979, 13 .

59 Since funding was never sufficient to implement the envisioned provincial plans entirely, policymakers created guidelines for determining the priority of potential new paths. They also used this strategy when they saw the need for utilitarian cycling paths since the 1970s. 


\section{Zuid-Holland Province Recreational Cycle Path Network,} 1962-1975

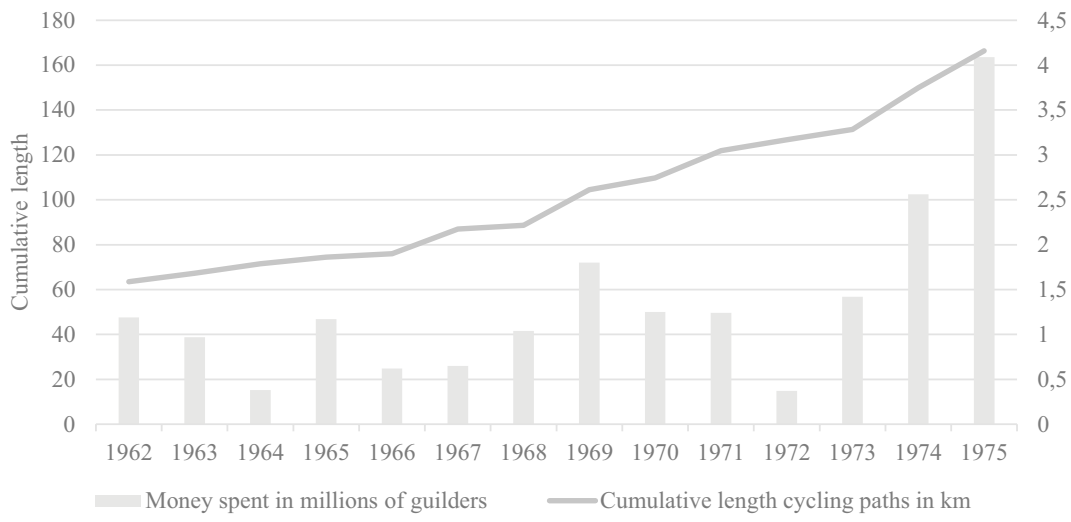

Figure 15 Funding for the Zuid-Holland cycling path plan fluctuated but supported a gradual increase of the network over the 1960s and 1970s. Source: J.P. Bakker and R. v.d. Hout, "Herziening provinciaal fietspadenplan Zuid-Holland,"Verkeerskunde 26, no. 7 (1975), 356.

more extensive participation design procedure. In a sign of the times, municipalities, recreational organizations, but also members of the public could comment on and revise the proposed plans.

Seeing cycling as a means to improve public health and wellbeing, provincial officials created a cycling path network and recreational areas for their (urban) residents. The energetic efforts of several provincial social democrat politicians who put pressure on Provincial Public Works engineers to take cycling more seriously, resulted in a progressive cycling policy for Zuid-Holland compared to many other provinces in the 1950s and 1960 s.

\subsection{0s National Subsidies for Recreational Cycling}

A national role in recreational cycling, briefly discussed in the 1930s, became only a reality in the 1960 s. The Ministry of Culture and Recreation began subsidizing recreational facilities, including cycling paths. ${ }^{60}$ In the 1970s, the Public Works ministry also subsidized (urban) utilitarian cycling infrastructure, as Chapter 7 explores. The national recreational subsidies were earlier, reflecting that the infrastructure for recreational cyclists received more political support in the 1950 s and 1960 s than for commuters, who were not entirely neglected. The national recreational subsidy 
entailed a 75 percent state contribution for cycling paths separate from the road network, leading through national parks, forests, and other attractive recreation areas. Appendix 1 lists the projects funded in the 196os, earlier than the construction of (activist inspired) urban cycling infrastructure. The 196os paths were mainly in provinces attempting to attract tourists and recreational cyclists. Provinces differed significantly in their proactive efforts to acquire subsidies. A 1976 consultancy report on recreational cycling and the associated policy processes noted these considerably different policies from province to province: "there is not one government in particular directing the policy process concerning recreational cycling." ${ }^{n 1}$ Policy coordination at a national level remained minimal.

The fact that (recreational) cycling was not declining as fast as some believed, spurred the national government to adopt a more proactive role. A 1961 Ministry of Culture, Recreation and Social Work committee meeting on outdoor recreation posed the question whether it still made sense to "invest large subsidy amounts in cycling paths in view of the advancing motorization." ${ }^{\prime 2}$ R. van de Waal, head of the National Planning Service's recreational branch (Rijksdienst voor het Nationale Plan) considered this type of thinking simplistic and warned against "the great danger of "catchphrases" [kreten] in determining policies." He referred to one popular catchphrase: "every young person rides a moped nowadays; the regular bicycle [trapfiets] is disappearing." However, "results of objective research often show a much more nuanced picture." ${ }^{\prime 63} \mathrm{He}$ cited 1956 research showing that during weekends, a third of the population left cities for recreation, often by bicycle. Even if this share dropped to 10 percent, he argued, that would still be 150,000 cyclists leaving cities at weekends. These absolute numbers justified investing in cycling infrastructure. According to another committee member, policy could be inspirational: "The presence of cycling paths - and familiarity with them - can stimulate cycling. ${ }^{n 4}$ Van de Waal pointed to recreational cycling's rising popularity in the United States as further proof that bicycles would no doubt never disappear altogether.

Cycling path construction up to this point had been mainly rural. The construction of urban cycling facilities really took off in the 1970s. As an intermediate step, policymakers increasingly focused on paths connecting

61 NA 2.27.5215, inv. no. 2167, letter consultancy agency C. Kappelhoff to A.A.H.C. van Onzenoort (Ministry of Culture and Recreation, Outdoor Recreation branch), December 20, 1976, attachment to letter, 54 .

62 NA 2.27.5111, inv. no. 6o, 28th meeting INCOR-committee, July 5, 1961.

63 Ibid.

64 Ibid. 
the city to the countryside. In their rich vocabulary for cycling facilities, Dutch engineers coined the term "break-out path" (uitvalspad). ${ }^{6}$ They were referring to paths that provided a safe, separate way to leave the city for short recreational rides or connect to nearby recreational facilities. Recreation officials increasingly saw the lack of such paths as problematic; city-dwellers who did not own a car were locked within the city's confines. According to W.G. van der Kloet, an engineer with the State Forestry Agency (Staatsbosbeheer) "especially during the weekend, traffic from residential areas to destinations in the vicinity can be very substantial, especially around cities. These paths fulfil an important role, especially if they can be extended to connect with the separate cycling paths being constructed - albeit not enough - in towns." ${ }^{n 6}$ Such paths would not be cheap but served commuters as well as tourists, making the expense more justifiable.

Initially, the coalitions focused on recreational cycling and only involved utilitarian cycling in the late 1960 s, as we will see. One typical example is the province of Limburg, where a cycling path committee (for recreational paths) created during World War II achieved very little. ${ }^{67}$ Even a new provincial committee to help establish a Provincial Cycling Path Fund for local communities in 1956 was discontinued twelve years later. ${ }^{68}$ This ended in 1968: according to the authorities, the municipalities did not use the fund sufficiently. A new funding opportunity for recreational and utilitarian cycling replaced it. Zuid-Holland province shows a similar pattern. Private organizations and provincial agencies framed cycling predominantly as a recreational activity until the late 196os, when the focus on utilitarian cycling returned. Triggered by recreational plans and the people behind them, the attention to utilitarian cycling broadened cycling path plans and subsidies. ${ }^{69}$

65 NA 2.27.5111 (Ministry CRM, INCORET = Interdepartementale Coördinatiecommissie Openluchtrecreatie en Toerisme), inv. no. 6o, 'Nota Rijwielpaden' by Ministry of Agriculture (Cultuurtechnische Dienst), attachment to letter to Ministry CRM/INCORET, August 16, 1963.

66 NA 2.27.5111 (Ministry CRM, INCORET = Interdepartementale Coördinatiecommissie Openluchtrecreatie en Toerisme), inv. no. 6o, Memorandum INCOR-315, attachment to Ministry of Agriculture letter to Ministry OKW/INCOR, June 12, 1962.

67 Frank Veraart and Adri A. Albert de la Bruhèze, "Fietsen in de Nederlandse bergen. Achterblijvend fietsgebruik in het zuiden van Limburg in historisch perspectief," in Studies over de sociaal-economische geschiedenis van Limburg/Jaarboek van het Sociaal Historisch Centrum voor Limburg, eds. Ad Knotter and Willibrord Rutten (Maastricht: Sociaal Historisch Centrum voor Limburg, 2001), 142.

68 Ibid., $145-48$.

69 When the Brabant organization De Kempen was founded in 1976, its aim was "mainly recreational paths, while now functional paths (those with a traffic function) are considered 


\section{$3 \cdot 4$ Conclusion}

In the 1950s, Dutch government policymakers framed recreational cycling as a public good by linking it with multiple policy goals. The province of Drenthe pioneered this strategy. Its leading politicians looking to combat unemployment and economic crisis as well as attract tourism and industry, saw cycling infrastructure as part of a package of measures. In Zuid-Holland, social democrat politicians held ideas - long-standing and widespread in and beyond the Netherlands - about cities' unhealthy impact on their residents. Ideas about green lungs and garden cities circulated transnationally. In the Interbellum, Dutch social democrat urban planners and public housing experts had emphasized the need for recreation - a notion provincial policymakers in both highly urbanized and tourist regions revisited in the 1950s. This time their motivation for building recreational infrastructure was economic: provinces with considerable nature reserves such as Gelderland or Drenthe were convinced a cycling path network would attract tourists - the kind of national tourism the ANWB promoted in its journal De Kampioen. Building on private organizations' earlier work and benefiting from the recreational cycling culture established before 1950, provincial policymakers in turn expanded cycling infrastructure.

Policy beliefs about recreational cycling developed at a time when regional planning ideas were equally strong. The result was a layered structure of national, provincial/regional, and local plans for land use, roads, and recreation. That these beliefs about cycling and governance coincided, helps explain why so many regional policymakers supported and initiated regional cycling plans. During the 1940 s and 1950s, the national government was noticeable by its absence from this story, while provincial authorities took the initiative. Despite the lack of national coordination, regional authorities regularly shared best practices. Only in the 196os did the national state start subsidizing recreational infrastructure on a larger scale.

Unlike in earlier decades, local politicians were the driving force. The ANWB's tourism and recreation lobbies played a background role by connecting people and institutions with relevant knowledge. However, the main initiative came from the ruling elites. Many mayors were personally involved in the organizations, as were leading provincial politicians and officials - a

by far the most important." Archive Eindhoven Regionaal Historisch Centrum, 10091 (Intergemeentelijke organisatie voor rijwielpaden in de Kempen, Valkenswaard), inv. no. 2, "Verslag bespreking studiecommissie heroriëntering taakstelling van de rijwielpaden-organisatie 10-09-1976." 
marked difference from the urban cycling activism that would emerge in the 1970s. The large and well-connected group of Dutch politicians who took an interest in recreational cycling also improved the connections for rural commuter cyclists. Mostly appointed and not elected, their longevity in office and continuing support for the policy were crucial. A stable corps of civil servants with whom cycling advocates could forge relationships was significant for urban cycling activism in the 1970 and beyond. Building these cycling infrastructure networks took decades, as competition for funding was a recurring theme. Engineering departments had many tasks and did not always prioritize implementing recreational plans. The piecemeal approach nevertheless produced significant results over time. The key players who made a real difference at the right time were social democrat politicians Stien de Ruyter-de Zeeuw and Joop Borgman in Zuid-Holland, and chief engineer Gerard van den Muyzenberg in Drenthe. Similarly, in a province not discussed here, Gelderland, Public Works chief engineer J.G. Kruimel was also the local representative (consul) for the ANWB. Like De Ruyter-de Zeeuw and Van den Muyzenberg, he had to struggle with a Public Works department that often objected to constructing cycling infrastructure and only reluctantly executed provincial policy. ${ }^{70} \mathrm{He}$ stimulated subsidizing cycling path organizations throughout his career, so it is not just Gelderland's natural areas but also his support that explains why so many organizations were formed here. ${ }^{1}$

By the late 196os, policymakers not only expanded recreational but also utilitarian cycling. The next section discusses this development, but the link with recreational cycling policies is important. After 1970, provincial policymakers and engineers remained the key intermediaries between national and local government - for negotiating subsidies, subsidizing cycling, and coordinating (the interconnectedness of) local cycling networks. Designing regional cycling path networks was an invaluable stepping-stone for the future.

70 GA o039, inv. no. 9488, letter PWS Gelderland to GS, March 28, 1949 and letter GS Gelderland to HID PWS, April 21, 1949.

71 "Fietsen op de paden van de Zuid-Veluwe," 176. 
